
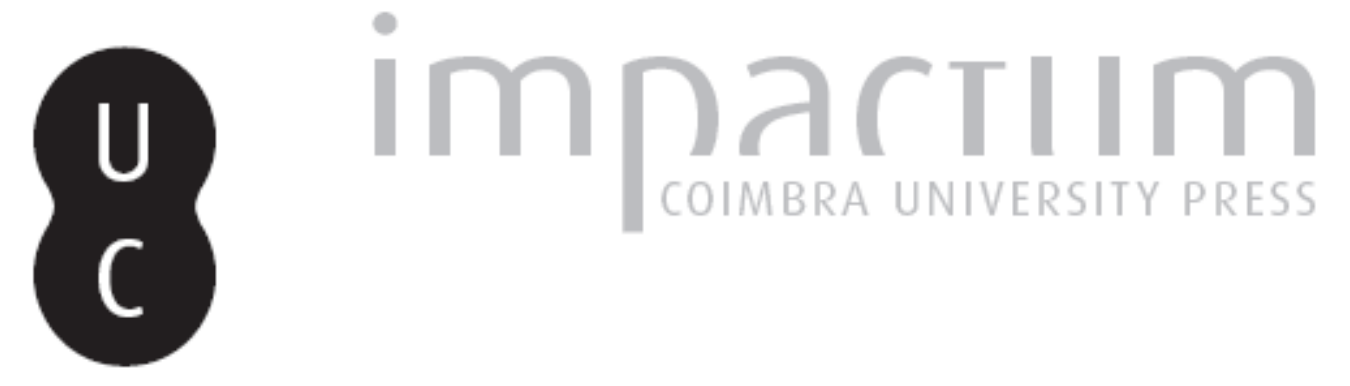

The stratification of citizenship in Europe: citizenship versus irregularity

Autor(es): $\quad$ Guia, Maria João

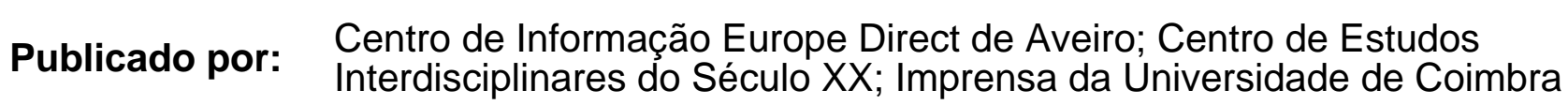

URL

persistente:

URI:http://hdl.handle.net/10316.2/39896

DOI: DOI:https://doi.org/10.14195/1647-6336_15_6

Accessed : $\quad$ 26-Apr-2023 11:47:47

A navegação consulta e descarregamento dos títulos inseridos nas Bibliotecas Digitais UC Digitalis, UC Pombalina e UC Impactum, pressupõem a aceitação plena e sem reservas dos Termos e Condições de Uso destas Bibliotecas Digitais, disponíveis em https://digitalis.uc.pt/pt-pt/termos.

Conforme exposto nos referidos Termos e Condições de Uso, o descarregamento de títulos de acesso restrito requer uma licença válida de autorização devendo o utilizador aceder ao(s) documento(s) a partir de um endereço de IP da instituição detentora da supramencionada licença.

Ao utilizador é apenas permitido o descarregamento para uso pessoal, pelo que o emprego do(s) título(s) descarregado(s) para outro fim, designadamente comercial, carece de autorização do respetivo autor ou editor da obra.

Na medida em que todas as obras da UC Digitalis se encontram protegidas pelo Código do Direito de Autor e Direitos Conexos e demais legislação aplicável, toda a cópia, parcial ou total, deste documento, nos casos em que é legalmente admitida, deverá conter ou fazer-se acompanhar por este aviso.

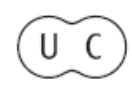




\section{DEBATER \\ A EUROPA}

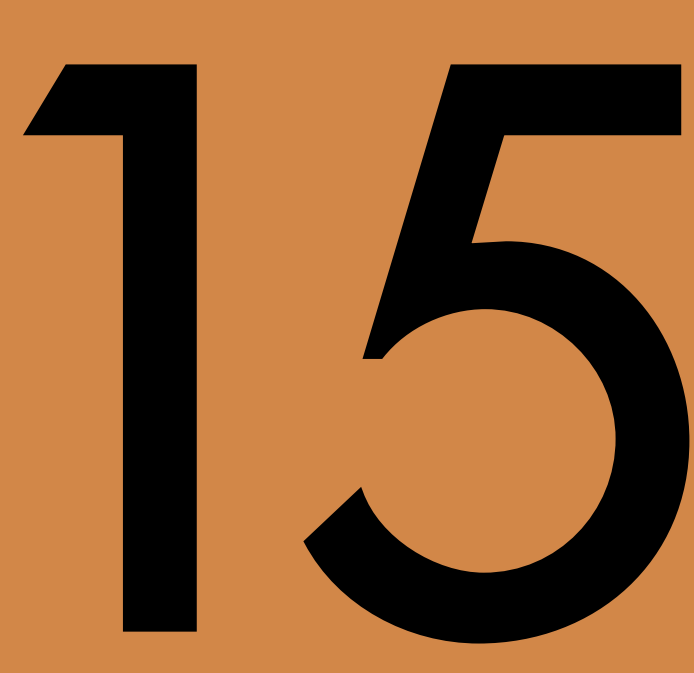

jul-dez 2016

PORTUGAL E A EUROPA.

30 ANOS DE INTEGRAÇÃO

PORTUGAL AND EUROPE.

30 YEARS OF INTEGRATION 


\title{
The Stratification of Citizenship in Europe: Citizenship Versus Irregularity
}

\author{
Maria João Guia, PhD \\ Coimbra University Centre for Legal Research \\ E-mail: maria.joao.guia@ij.uc.pt
}

\begin{abstract}
Citizenship functions not only to connect the individual to the sovereign state, but acts to induce feelings of belonging to a certain society. In this scope, managing the irregularity of migrants positions citizenship as a form of gatekeeping, controlling access to society and restraining those who seek it from accessing social membership. In this article, I outline the process by which European stratified citizenship has resulted in the loss of access to rights. This outline will serve to demonstrate how irregularity management strategies, be they high intensity criminalisation strategies as reflected throughout the EU or low intensity with integration measures as seen in Portugal, cumulate in the denial (or concession) of certain categories of people from citizenship.
\end{abstract}

Keywords: irregularity; citizenship; stratification; EU high intensity criminalisation

\section{Introduction}

Over recent years, public discourse has become increasingly fixated upon migrationrelated issues. Such discussions have been particularly prevalent among politicians and in the world of academia ${ }^{1}$. This discourse has revolved around not only the everchanging phenomenon of international migration, but has embraced wider concerns

\footnotetext{
1 This article is an excerpt from the PhD thesis of the author. GUIA, Maria João, PhD Thesis. Immigration, 'Crimmigration' and Violent Crimes. The Convicted Inmates and the Representations of Immigration and Crime. University of Coimbra, 2015. The author wants to express her gratitude to João Pedroso.
} 
about border control and security of host nations, migrant integration (although, according to recommendations of the Council of Europe ${ }^{2}$, the concept of 'integration' should be interrogated), the social exclusion which migrants are forced to endure, racism, citizenship, human rights, et cetera. According to Directive 2008/115/EC of the Parliament and of the Council, 16 December 2008, paragraph 4 of Article 3, the return decision as follows: "return decision' means an administrative or judicial decision or act, stating or declaring the stay of a third-country national to be illegal and imposing or stating an obligation to return".

\section{Brief perspectives of citizenship and belonging through the ages}

'Just magnify our right to life fulfilling our duty as citizens of the world'.

Mohandas Gandhi

The term 'citizenship' comes from the Latin civis, which means the position of the individual in civitas, the 'city'. In a broader sense, citizenship is used to describe one's membership to a politically cohesive community and the consignment of rights and obligations enjoyed by all free people who comprise said community. ${ }^{3}$ In the democracy of Athens and the Roman Republic, citizenship meant to belong to or be a member of a specific community ruled by those same citizens. ${ }^{4}$ We cannot, therefore, reflect upon this concept without briefly evoking these two great civilisations whose citizenship models have become the pillars upon which our political life and the basic rules of our community rest.

\footnotetext{
2 ،...the evaluation or measurement of integration has to begin with a definition of the basic terms... what exactly is meant by the term 'integration' is of great importance. Without common standards as to what is meant by 'migrant' and by 'integration' all attempts to measure migrants' integration in different countries are likely to be of little meaning...'[Accessed in 01.01.20...] Available at http://www.ceps.eu/system/files/EIF\%20conference\%20programme.pdf

${ }^{3}$ LUÑO, Antonio-Enrique, 'Ciudadania y definiciones'. In Doxa. Cuadernos de Filosofia del Derecho. Alicante, №25,2002, pp. 177-210. See also www.eurocid.pt.

${ }^{4}$ BAUBÖCK, Rainer (Ed.), Migration and Citizenship. Legal Status, Rights and Political Participation. IMISCOE Reports. Amsterdam University Press,2006
} 


\subsection{Classical citizenship, 'the other' and the construction of power}

In classical Greece ( $5^{\text {th }}$ century B.C.), especially in the Athenian model, the meaning of citizenship was rather broad and focused on the active participation of citizens in public decision making. In contrast to the active citizen who reserved the right of participation in the political community, the metics ${ }^{5}$ were effectively 'resident aliens', individuals excluded from those same rights exercised by those who were part of the polis, but still obliged to perform military service and to excise all other civic duty. ${ }^{6}$ In addition, non-resident foreigners in the city-who had a protector (i.e. Zeus Xenios)—were considered a distinct class, known as xénos, which means friend or guest. The xénos was effectively 'someone has friendly ties of which derive duties and reciprocal rights'.).

However, Athens not only accepted foreigners, but went so far as to encourage them to be present in the polis wherein lay the nitty-gritty of citizenship, as birth connected the individual to the site of their birth and to the community (koinonia) (Cândido et al., 2008). Thus, neither xénos (foreigners and guests) nor metics (resident aliens), although welcomed, had access to the same statutory rights as Athenian citizens because they did not share the same Athenian identity. ${ }^{7}$ Nonetheless, sometimes a foreign (metóikos ${ }^{8}$ or xénos) made such contributions to democracy as to be considered deserving of Athenian citizenship. In such cases, the non-citizen exhibited every indication of inclusion, having fulfilled their civil duties, but he acceded to only 'limited participation in national activities', never acceding entirely to the same rights of an Athenian citizen (). The explanation of this contradiction is based on the Laws of Pericles, that stated that the Athenian citizen was only such when both parents were Athenian. Everyone else was excluded from citizenship and could lose that conceived accesses if voted atimia $^{9}$ for having committed 'a serious offense held against polis'.

\footnotetext{
5 The word comes from the Greek metoikos meaning 'residing' and results from the goal preposition junction ('amid') with the noun oikos ('home', 'family-owned') and meant 'He who lives together'. According to David Whitehead, the target preposition implied motion in that metoikos had the idea underlying movement and migration. According to Peter Jones (apud Candido, 2008: 31) meant 'resident alien, or non-Athenian citizen who lived for more than a month in Athens.

${ }^{6}$ CÂNDIDO, M. Regina; GRALHA, Júlio César; BISPO, Cristiano Pinto; PAIVA, José (orgs).. "Vida, Morte e Magia no Mundo Antigo". Rio de Janeiro: NEA/UERJ. Anais da VII Jornada de História Antiga, Suplemento II, 2008 . [Accessed in 26/07/2010] Available at: http://www.nea.uerj.br/publica/ebooks/vida_morte_e_magia_no_mundo_antigo.pdf.

${ }^{7}$ Idem.

${ }^{8}$ See footnote $\mathrm{nr} 4$.

${ }^{9}$ Total or partial removal of civil rights and political functions in Athens.
} 
The politeia determined, according Lisia, Isócrates and Demosthenes, one's access to political rights, thus strengthening the collective and social character that the concept of citizenship entailed. This strong link between political rights and the notion of citizenship, through the concepts of equality (according to which one should be respected equally before the law) and isegoria (the right to have a voice in the assembly), leads us to conclude that the concept of citizen in the Greek model was indelibly linked to participation in the political and public life of the society. Note that rights under the Politeia were transmitted only to male children; women, who were excluded from citizenship, could obviously not pass citizenship on to their children. Like women, slaves and metics were similarly deprived of political rights.

Aristotle defined the citizen (politaí) as an individual who follows polis decisions in which the people 'rules for public utility'. ${ }^{10}$ This meaning of polis reflects the nature of man, which is at the core of citizenship. Consequently, the citizen was anyone actively participated in political life, leading discussions in the Agora ${ }^{11}$ and who actively participated in decision-making. As such, the rights and duties of individual citizens had practical implications for all other individuals (not just the ones who lived in a given territory). ${ }^{12}$

Denis Diderot similarly described the active participation of individuals in building society, defining the citizen as 'a member of a free society composed of many families who participate in this society'. (Diderot stipulated a number of criteria for the cognition of citizenship. Firstly, citizenship is the 'personhood living in a free society'. As such, the presence of a dictatorship or absolute power negates the possibility of pure citizenship. Secondly, citizenship 'is a voluntary condition that cannot be imposed on anyone'. According to this principle, the individual reserves the right of migration, being free to use their free will to choose, change or renounce their original citizenship and the place in which they can exercise their rights and duties in the new state, regardless of where they may have acquired their citizenship. This premise sees the differentiation between two types of citizenship: original citizenship (which is closely related to the acquisition of nationality) and acquired citizenship (which relates to the manifestation of the will of the citizen). Finally, citizenship 'unfolds in a series of rights

\footnotetext{
${ }^{10}$ CUNHA, Paulo , Aristóteles - Filosofia do Homem: Ética e Política. 2003.[Accessed in 20/07/2010] Available at: http://www.hottopos.com/rih8/pfc.htm\#_ftn1

${ }^{11}$ Agora is the central public square of the polis.

${ }^{12}$ MALTEZ, José, 'Tópicos Políticos. Breves tentativas de definições conceituais', elaboradas por um professor em regime de sabática. Cidadania, o que é?, 2004. [Accessed in 19/07/2015].Available at: http://topicospoliticos.motime.com/
} 
and duties of persons belonging to a particular state', and, according to this perspective, not all people who are part of a community will be considered citizens (women, children and servants) ${ }^{13}$, and only participate in society by ties that bind them to the real citizens.

\subsection{Modern citizenship, 'the other' and the construction of rights}

The French Revolution of 1789 saw the birth of the modern society. In this new society, the individual is seen from two perspective: (a) as an individual enjoying private rights; and (b) as a collective being with rights and duties owed to other individuals that make up the social fabric of which he himself is part. Citizenship to this new society, therefore, entailed the 'right to life, liberty, property and equality before the law'. ${ }^{14}$ This was the revolution of all citizens and this renewed meaning of citizen is the 'nerve centre' of all of the rights and freedoms granted to members under the rule of law: 'Citizenship, Fundamental Rights and rule of law are not only legal categories politics emerging from the same historical climate, are realities that affect and involve each other'. ${ }^{15}$

Following the French Revolution, the inequalities reported by Karl Marx (e.g. sequential bourgeois citizenship) were increasingly criticised. This bourgeois conception of citizenship distinguished men into two categories: those with an uneven performance in the society and those who were holders of public relations in the political community.

In the opinion of Thomas Marshall, the citizen should benefit from the capacity to exercise full social, economic and cultural rights, including a plurality of privileges. Marshall sought to ensure that this liberal concept of citizenship could be questioned and discussed.

\footnotetext{
${ }^{13}$ These considerations must be examined in the light of the time they were reflected.

${ }^{14}$ ABRANTES, Raniery , Cidadania, política e poder,2010. [Accessed in 26/07/2010] Available at: http://www.pbagora.com.br/coluna.php?id=20100525113257\&cat=politica\&keys=cidadania-politicapoder\&enviar $=\mathrm{s}$,.

${ }^{15}$ LUÑO, Antonio-Enrique "Ciudadania y definiciones" Doxa. Cuadernos de Filosofia del Derecho. 2002: 25, 177-210.
} 


\subsection{Contemporary citizenship, 'the other' and the construction of}

\section{inequalities}

With modernity, citizenship has been renamed 'membership' and has come to describe a legal relationship a defined by a particular rule of law (political rights or participation in state life). This conception of citizenship implies that rights, including political, social and civil rights are won by fighting. Therefore, belonging to some community, as well as participating in it, implies the possibility that exclusion might be more concrete and strong, to the extent that those who do not meet these assumptions will not have access to such citizenship.

This new conception of citizenship furthered the theoretical and practical outcomes of the modernity project that started with the Enlightenment. Marshall addressed three types of citizenship: legal (in court), political (parliamentary) and social (welfare state). ${ }^{16}$

Kofman states that citizenship means rights and duties to which citizens of a particular nation-state are linked. ${ }^{17}$

Bellamy emphasises rights, participation and solidarity as the main elements of contemporary national citizenship (i.e. civil rights that protect individual autonomy and the family; participation rights in political life; and access to social rights, such as education and security social). ${ }^{18}$ Formally, citizenship is a legal status, being in its broadest sense, the culmination of the merger in society' ${ }^{19}$

Citizenship is a process that is under constant construction; reflecting the connection between the individual and the state, in that citizenship recognises the right of the individual to participate in the community. ${ }^{2021}$

\footnotetext{
${ }^{16}$ MARSHALL, T.H. 'Citizenship and Social Classes', in T.H. MARSHALL and Tom BOTTOMORE (orgs.), Citizenship and Social Class. Londres: Pluto Press, 1950, pp. 3-51.

17 KOFMAN, Eleonore (1995) "Citizenship for Some but not for Others: Spaces of Citizenship in Contemporany Europe” Political Geography. 14(2), 121-137.

18 BELLAMY, R., 'Introduction: The Making of Modern Citizenship', in R. Bellamy et al. (eds), Lineages of European Citizenship: Rights, Belonging and Participation in Eleven Nation States. Basingstoke: Palgrave Macmillan, 2004.

${ }^{19}$ CURRIE, Samantha (2008), Migration, Work and Citizenship in the Enlarged European Union. Surrey: Ashgate, 2008.

${ }^{20}$ MENEZES, Manuel (2001) “A Cidadania que Desejamos! Aproximação Analítica às 'Teorias' da Cidadania" in Menezes, Manuel (org.) As práticas de cidadania no poder local comprometido com a comunidade. Coimbra: Quarteto, 21-48.

${ }^{21}$ CARVALHO, Cláudia, Dinâmicas Culturais e Cidadania: as culturas Locais na Pós-modernidade. Um Estudo de Caso. Dissertação de Mestrado. Universidade de Coimbra. 2004
} 
While ambitious in theory, these concepts lead us to consider the lived experience of citizenship, especially by immigrants, through the tumultuous changes that have taken place across the world, and especially Europe, following the implementation of the Schengen Agreement, which provides for the free movement of persons by signatory countries.

The unilateral and multilateral facets of citizenship relate to the parties involved. The unilateral perspective on citizenship is primarily concerned with the relationship between the individual and the state, while the multilateral perspective includes a plurality of citizenship. The study of citizenship should not, however, be confined to the different language meanings, syntactic, lexical or semantics that the term can acquire, but look to its diachronic and geographical evolution.

\section{European citizenship or stratification of citizenship?}

Since Portugal joined the European Community ${ }^{22}$ in 1986 , came to see national legislation subject to the supremacy of that which would be statutory by European institutions (i.e. community law). The Community Treaties came to be a source of rights and obligations to be followed, not only by nationals of member countries, but also by those who resided in those states ${ }^{23}$, thus having:

'An ability to produce legal effects on the legal rights of citizens, creating them rights or imposing obligations on them, 24

\subsection{The construction of European citizenship}

The notion of Union citizenship complements that of national citizenship. ${ }^{25}$ However, European citizenship, provided for in the Maastricht Treaty of 1992, exists only in so far as the individual is a citizen is a one of the Member States of the European Union.

\footnotetext{
${ }^{22}$ Resulting term of the Maastricht Treaty (Urbano de Sousa, 2004).

${ }^{23}$ That is why citizens (individuals) have the right to pursue in the courts by any non-compliance with a duty imposed by the rules of Community law and the duty not fulfilled by the Member State (public authority) concerned ).

${ }^{24}$ SOUSA, Constança Urbano de , 'Direito de Asilo'. In Janus, 2004. [Accessed in 18/06/2010]. Available at: www.janusonline.pt,

${ }^{25}$ SHAW, Jo "The Interpretation of European Union Citizenship". In Modern Law Review. 61(3), 1998, pp: 293-317.
} 
European citizenship provides for:(a) freedom of movement ${ }^{26}$ and the right of residence in any Member State; (b) the right to vote in Member State of residence elections (provided that it is a European or municipal election in the state); (c) the right to benefit from the diplomatic protection of any Member State other than that which they belong (there being representation in the State where the citizen is in); and (d) the right to complain to the European Ombudsman and petition the European Parliament (Treaty of Maastricht, 1992).

In the early $21^{\text {st }}$ century, the European Union agreed to the entry of ten more member countries ${ }^{27}$, bringing its membership to 25 . Consequently, the European population increased by $28 \%$ to more than 500 million inhabitants. ${ }^{28}$ Three years later, with the entry of Romania and Bulgaria, the European Union population now represented 529 million people and 27 countries (Lanzieri, 2007:1) ${ }^{29}$, which recently included Croatia and another 4.5 million inhabitants ${ }^{30}$. Although the integration of these new states has been accepted, studies predicted that following the entry of these countries into the European Union, about 335,000 workers would travel to the western states in search of better living conditions. Fearful of these problems, there has been talk about restricting the bulk movement of immigrants from new member countries for 7 years. Restrictions were thus placed on citizens from the eight Eastern European countries that joined in 2004 and the other two whose accession took place in 2007. These ten countries have seen the free movement of their citizens restricted for seven years during the transition period following their entry into the European Union. This move essentially contradicts the Union's recognition of academic and professional qualifications, the right to family reunification and to other social rights owed to European citizens in light of the right to free movement. ${ }^{31,32}$. As such, this gives rise to

\footnotetext{
${ }^{26}$ According reflections Bittar, is questionable management that states can make this profound change brought about by the free movement: 'Are the cultures prepared for a living, still considered strange, due to the circulation to all parts of world citizens (Welbürger)?' BITTAR, Eduardo (2006) "Cosmopolitismo e Direitos Humanos" Depoimentos - Revista de Direito das Faculdades de Vitória. 10, 11-26.

${ }^{27}$ Czech Republic, Estonia, Hungary, Latvia, Lithuania, Poland, Slovenia and Slovakia, as well as Malta and Cyprus.

${ }^{28}$ VAUGHAN-WHITEHEAD, D.C., EU Enlargement versus Social Europe? The Uncertain Future of the European Social Model. Cheltenham: Edward Elgar, 2003.

29 LANZIERI G., 'EUROPOP2007 Convergence Scenario: summary note'. Working paper ESTAT/F1/PRO(2007)02/GL presented at the Joint meeting of the Eurostat Working Group on Population Projections and of the ECP Working Group on Ageing Populations and Sustainability, Luxembourg, 2930 November 2007.

${ }^{30}$ Croatia had 4,480,043 inhabitants in 2011, according to the index mundi population. Accessed on July 29, 2013 in http://www.indexmundi.com/pt/croacia/populacao_perfil.html

${ }^{31}$ Even if there are legislated specifications that have generally been met, especially if family values and children are concerned.
} 
an excluded class: 'the fear of labour market invasion by workers from eastern and central Europe, led to the emergence in the Union, albeit temporarily, of "second class" citizens'. ${ }^{33}$ The International Organization for Migration (IOM) did not believe that the inclusion of new Member States into the European Union would provoke mass emigration into the old 15 states. It turned out, however, that the fight against irregular immigration and human trafficking were problems that the new Member States needed to address ${ }^{34}$, while the 2013 report released by Frontex ${ }^{35}$ on the Annual Risk Analysis of the western Balkan region indicates that these areas has become the point of origin for many undocumented migrants.

These changes have forced members of the European Union to meet to try to standardise the criteria for immigrant entry and staying. A consensus was reached in 1985 to implement the Schengen Agreement, an agreement regulating the entry and exit of people ${ }^{36}$ and objects to the common space of signatory countries and to implements a common immigration policy at the point of origin. These objectives were solidified following the Treaty of Amsterdam in 1999, in which member countries committed themselves to a common set of immigration and asylum-seeking policies and agreed to fight against immigration-related crime. Subsequent policies have been in effect since 2004

The Schengen Agreement and the terms of the Schengen Implementing Convention were put effective as of 25 March 1995. Subsequent procedures with regards to the visa requirements were harmonised by signatory countries. Consequently, the concept of an external border has changed significantly, now designating the separation between Schengen Agreement signatories and other (i.e. third) countries. Portugal, consequently, began to take a more active role in the management of external borders, especially given its geographical situation. In 2000, the number of immigrants

32 CURRIE, Samantha Migration, Work and Citizenship in the Enlarged European Union. Surrey: Ashgate, 2008.

${ }^{33}$ PAIS, Sofia O. "Todos os cidadãos da União Europeia têm direito de circular e residir no território dos Estados-Membros, mas uns têm mais direitos do que outros..." In, Scientia Iuridica, 323, 2010, pp: 467496.

${ }^{34}$ Accessed in 20/06/ 2014l. Available at

http://europa.eu/legislation_summaries/justice_freedom_security/fight_against_trafficking_in_human_bei ngs/j10058_pt.htm to

${ }^{35}$ Frontex Annual Risk Analysis 2013. European Agency for the Management of Operational Cooperation at the External Borders of the Member States of the European Union. Warsaw, Poland, 2013. http://frontex.europa.eu/assets/Publications/Risk_Analysis/Annual_Risk_Analysis_2013.pdf [6 de fevereiro de 2015].

${ }^{36}$ Currently, the 'United States of the European Union' host annually between 300,000 to 500,000 new legal inhabitants (returnees, foreigners who requested family reunification, new immigrants and asylum seekers), plus about 500,000 illegal immigrants, although not all of the latter are able to remain in Europe. 
from countries outside the European Union amounted to 15 million, living among the 380 million residents in the 15 Member States. In 2006, the estimated number of immigrants in the European Union amounted to 40 million. Considering this number, along with the many millions of descendants, the 26th Member State of the EU (before the accession of Member States in 2007) summed up their population as the fifth largest population in the world. ${ }^{37}$

However, it must be noted that there is no "complete coincidence between the external borders and the member countries of the European Union', as not all European Union countries are signatories to the agreement. According to Boaventura de Sousa Santos there was 'a de-territorialization of internal borders and a repossession of external borders' which also led to a change in the rights granted to these migrants. ${ }^{38}$

\section{The Stratification of European citizenship: the levels of irregularity in EU and Portugal}

The notion of citizenship of the European Union co-exists alongside that of national citizenship(s). ${ }^{39}$ Consequently, an increasing number of rights have been imported for the benefit of non-national residents, primarily those with long-term residency status, including the right to be recognised as a citizen of the receiving society without losing one's original nationality. This has allowed a number of migrants to access citizenship rights in a manner almost as egalitarian as that afforded to natives. Transnational citizenship has become part of the wider transformation of the migratory field that has become more visible due to the proliferation of multiple nationalities. ${ }^{40}$

However, focusing specifically on citizenship to the European Union, according to the Maastricht Treaty (1992), the Union's obligation to recognise such citizenship arises only so far as the alleged European citizen is a national of one of its' Member States. European citizenship provides for: firstly, the free movement of persons and the right of residence in any of the Member States; the right to vote in elections in the Member State of residence (provided it is European or municipal elections this State); the right to benefit from diplomatic protection of any Member State other than that which s/he

\footnotetext{
${ }^{37}$ Resolution of the European Parliament, 2006.

${ }^{38}$ SOUSA SANTOS, Boaventura de, Sociología Jurídica Crítica. Para un nuevo sentido común en el derecho. Madrid: Trotta, 2009.

${ }^{39}$ SHAW, Jo "The Interpretation of European Union Citizenship" Modern Law Review. 1998. 61(3), 293317.

${ }^{40}$ BAUBÖCK, 2006.
} 
belongs (there being representation in the State where the citizen is in); and, the right to complain to the European Ombudsman and petition the European Parliament (Treaty of Maastricht, 1992). The theory of fundamental rights allowed the expansion of social rights. The EU Charter of Fundamental Rights of 7 December 2000 (Nice)—now part of the Lisbon Treaty-outlines the social, civil, political, and economic rights of European citizens, as well as all those residing therein. These rights are divided into six categories: dignity, freedom, equality, solidarity, citizenship and justice. ${ }^{41}$.

Marshall espoused the idea of 'structural inequality', in which citizenship functions as a 'regulator (...) redistributing rights, balancing the structure of society'. ${ }^{42}$. However, theory and practice were often incongruent. In theory these rights embodied the indelible values of equality, civic participation and access to rights; but in practice, a form of inequality was being instituted that put citizens in different price levels: 'there can be compatibility between equal participation in society, that is, equal citizenship, and inequalities offered by social stratification'. ${ }^{43}$ Not only was there a stratification of citizenship, but also the empowerment of rights were stratified over the years, following achievements over time. First, the conquest of civil rights in the $18^{\text {th }}$ century ${ }^{44}$, followed by the acceptance of political rights ${ }^{45}$ in the $19^{\text {th }}$ century, and social rights in the $20^{\text {th }}$ century. Encompassed in the latter are access to economic well-being, participation, education, and social benefits. ${ }^{46}$

To check if there is a possible stratification of citizens in the Portuguese society (Portuguese and non-nationals), we firstly have to understand immigration movements in Portuguese society. In a very brief analysis, there were many factors that may have contributed to the change in the '90s, especially concerning the entry of immigrants in Portugal. Factors such as the widening economic inequality in Eastern European countries, mainly due to wars and conflicts (some of them religious); the change and complexity of the globalisation processes requiring a redirection of capital flows; new

\footnotetext{
${ }^{41}$ NETO, Diogo, Sistema Admnistrativo Sancionador e Direitos Fundamentais. Algumas Considerações Sistemáticas, 2008. [Accessed in 03/08/2010] Available at http://www.iiede.org.br/arquivos/sistemaadministrativosancionadoredireitosfundamentais2.pdf

${ }^{42}$ MOURA, Aline, "Da Cidadania "clássica" à cidadania "global": nacional versus supranacional". In Revista Jurídica - CCJ/FURB v. 13, n 25, 2009, pp. 45-64.

43 idem

${ }^{44}$ These include the right to individual freedom and of the law (including religious freedom of thought and expression), an association of law, economic initiative, property, and contract (Branco, 1995).

45 These include the right to be part of the political power and to vote and be elected and to hold public office (Branco, 1995).

${ }^{46}$ These rights are exercised mainly from the educational and social systems and result in minimal and economically balanced life, depending on the historical circumstances of the moment.
} 
patterns and changes in the supply of skilled labour, new patterns of international competition and the abolition of borders in the European Union space have all contributed to the changing migration landscape in Portugal. ${ }^{47}$

According to the statistics, up until the middle of the '70s, immigrants were not a significant demographic in Portugal. The 1960 census registered 29,000 foreigners living in Portugal. ${ }^{48}$ In 1975, there were around 32,000 immigrants living in Portugal. ${ }^{49}$ Over the following decades, the foreign population living in Portugal has risen considerably, as can been seen in the 30 year period outlined in Table 1 .

Table 1. Total population in Portugal, Portuguese and non-nationals, legally and authorised $(\mathbf{1 9 7 0 - 2 0 1 2})^{50}$

\begin{tabular}{|c|c|c|c|}
\hline Year & Total population & $\begin{array}{c}\text { Foreign residents and } \\
\text { authorised people residing in } \\
\text { Portugal }\end{array}$ & $\%$ foreigners \\
\hline $\begin{array}{ll} & 197 \\
0\end{array}$ & 8611110 & 31505 & $0,4 \%$ \\
\hline $\begin{array}{ll} & 198 \\
1 & \end{array}$ & 9819054 & 54414 & $0,6 \%$ \\
\hline $\begin{array}{ll} & 199 \\
2 & \end{array}$ & 9950029 & 123612 & $1,2 \%$ \\
\hline $\begin{array}{ll} & 200 \\
1 & \end{array}$ & 10330774 & 350898 & $3,4 \%$ \\
\hline $\begin{array}{ll} & 201 \\
0 & \end{array}$ & 10573479 & 445262 & $4,2 \%$ \\
\hline $\begin{array}{ll} & 201 \\
2 & \end{array}$ & 10542398 & 417042 & $4,0 \%$ \\
\hline
\end{tabular}

* These numbers were obtained by the sum of residence permits and permanence authorisations.

\footnotetext{
${ }^{47}$ BAGANHA, Maria I.; Góis Pedro "Migrações internacionais de e para Portugal: o que sabemos e para onde vamos?" Revista Crítica de Ciências Sociais. 1999. 52/53, 229-280.

${ }^{48}$ BAGANHA, Maria I.; Marques, José Imigração e Política: o Caso Português. Lisboa: Fundação LusoAmericana. 2001.

${ }^{49}$ ROCHA, João L. Reclusos Estrangeiros: Um Estudo Exploratório. Coimbra: Almedina. 2001.

${ }^{50}$ We need to be cautious when analysing this data. The sum calculated for the number of foreigners living in Portugal was done with available data. Care should be taken when analysing available data.
} 
** This number was obtained by the sum of the residence permits in 2005, permanence authorisations granted and extended in 2005 and the extension of longterm visas that comprise labour visas, temporary stay visas and study visas, in 2005 (Guia, 2008).

*** Source: Estimates of resident population in Portugal, INE 2005 ${ }^{51}$ (Guia, 2008)

Source: INE 2005, Statistcs SEF, author's calculations, Eurostat Population on 1 January 2.4.0-r1-2014-12-11 (PROD $\left.)^{52}\right)$.

Migrants' countries of origin, as well as their sociodemographic profiles, have also changed during these years, suggesting a "progressive complexification of the composition of the foreign population in Portugal'. ${ }^{53} \mathrm{We}$ should also refer to the rapid increase in Portugal's foreign population in relation to the growth of Portuguese nationals. In 1981, the foreign population consisted of 54,414 people; one decade later, there were 113,978 foreign-nationals. Five years later, Portugal's foreign population had increased by $48 \%$, with 168,316 people. Around the year 2000, Permanence Authorisations were created. This document enabled regularisation in Portugal to those who had no permit and who met certain requirements. With this document, migrants could legally work and stay in Portugal for up to one year. This document was renewable every year for five years. After that, it was possible for those people to apply for a longer validity document, a Residence Permit, already granted before the establishing of the Permanence Authorisations. Consequently, between 2001 and 2005, more than 183,833 immigrants benefited from this measure. In 2005, there were over 414,717 foreign-nationals living in Portugal. In 2012, foreign nationals accounted for 4\% $(n=417,042)$ of Portugal's population. More than half of the Permanent Authorisations were assigned to two countries: Ukraine (35.2\%) and Brazil (20.7\%). From this very brief analysis, we can conclude that during the period in which Portugal undertook three extraordinary regularisations, there were already a number of migrants

\footnotetext{
51 GUIA, Maria João (2008) Imigração e Criminalidade - Caleidoscópio de Imigrantes Reclusos. Coimbra: Almedina.

52 GUIA, Maria João, PhD Thesis. Immigration, 'Crimmigration' and Violent Crimes. The Convicted Inmates and the Representations of Immigration and Crime. University of Coimbra, 2015.

${ }^{53}$ Vide nota 48.
} 
living in irregularity, especially in the post-2000 period. This regularisation measure doubled the population of foreign residents living in Portugal.

It is also interesting to observe that Portuguese law has improved somewhat in relation to the increase in the foreign population. This situation has come about in part due to the need to follow European directives, but out of a national desire to improve the living conditions of the migrant population. With the entrance of non-national citizens, receiving countries gain a number of important demographic, economic, cultural, and sociological advantages.

Moreover, from this analysis, we can see that a stratification of irregularity emerged divided between two groups: those with access rights (regular/legal migrants) and those who were denied those same access rights (irregular/migrants in illegality).

Figure 1 is a representation of the stratification of access to citizenship rights. Citizens in regularity are designated 'Group 1' and those living in irregular permanence, 'Group 2'. Nevertheless, for this analysis, we will only concern ourselves with how individuals in irregularity have been granted differential access to certain types of rights, depending on their relationship to their destination country.

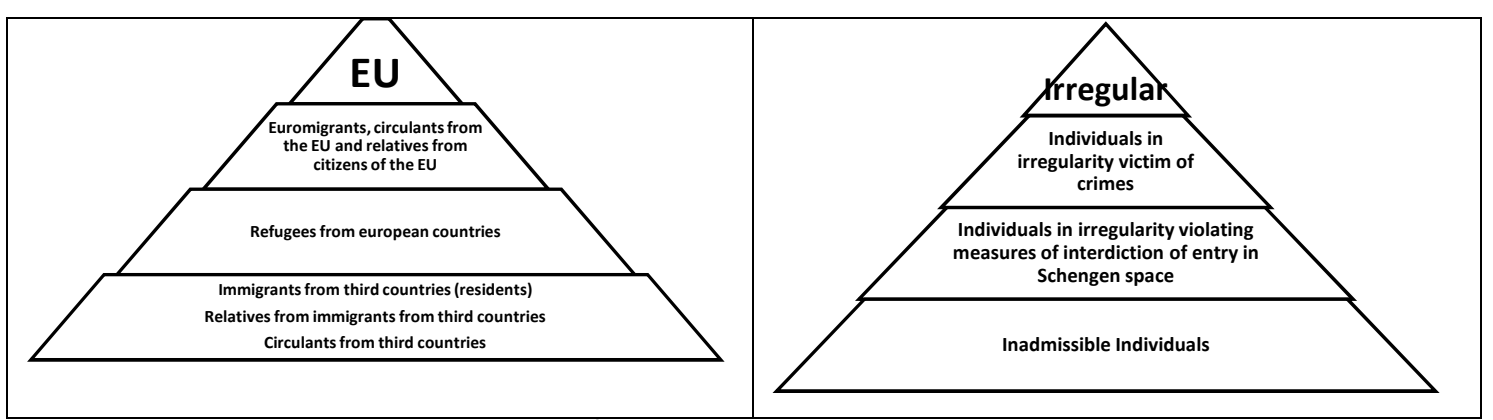

Figure 1. Citizens in regularity ${ }^{54} \&$ irregularity and their stratification ${ }^{55}$

In consideration of Figure 1, it becomes apparent that citizens of the European Union have access (or should have access) to the entire body rights, including the major political ones, recognised by the European Union. Nevertheless, to be elected National President, one must still have been born in Portugal, for instance. For the purposes of

\footnotetext{
${ }^{54}$ Those born, live and remain in a country of the EU, cf. Article 2, paragraph a) of Act No. 37/2006, of August 9 'a) "Union citizen" any person who is a national of a Member State'. Although our intention was to give a more general European perspective on the subject is necessarily have to go with exemplifying the Portuguese case, since European citizenship is still under construction and there are discrepancies between various States, which would make the analysis of this point by the plurality of images not proceeded not to be the central theme of our article.

${ }^{55}$ GUIA, 2015
} 
this analysis, however, we will limit ourselves to stratified non-regular immigrants: listing euromigrants ${ }^{56}$, European Union circulating migrants ${ }^{57}$, family members of European Union citizens ${ }^{58}$, refugees from third countries, immigrants from third countries (residents ${ }^{59}$ ), relatives from immigrants from third countries, and circulants from third countries ${ }^{60}$.

Within the second group of irregular migrants, we also find a scaling of access to rights, as can be seen in Figure 1. Briefly, Figure 1 reflects a scale of invisibility.

Who are they? Individuals in Irregularity: Persons from third countries, who do not have the required documents to travel, live and work in a European Union country. Individuals in Irregularity Victims of Crimes: Individuals from third countries who do not have the required document to travel, live and work in a European Union country and who are victims of crimes by a network or by private individuals. In the case of achieving access to justice, they possibly move to the next layer/level (Fig. 1), since legislation grants them certain rights in addition to those given should they wish to cooperate in investigations ${ }^{61}$. Individuals in Irregularity in Violation of Entry Ban Measure in Schengen Area: Individuals from third countries who do not have the documents required to enter, travel, live or work in a European Union country and who have a deportation order and concomitant entry ban measure in the Schengen area for a certain period of time, do not obey and return later and are detected. Note that this violation is a criminal offence, as stated in Article 187 of Law 23/07 of 4 July, 2007. Inadmissible Individuals: Citizens presenting at border posts who do not meet the requirements to enter the country, who are not permitted any access to the national

\footnotetext{
56 The citizens from an EU country who decide to establish their lives in another EU country (Guia, 2015.).

${ }^{57}$ The citizens from an EU country who decide to spend some time (in tourism, study, internship, etc.) in another EU country without establishing their lives; (cf. GUIA, 2014.) GUIA, Maria João (2014) "Quatro em Linha - um jogo de exclusão: - Imigração, Nacionalidade, Cidadania e Crime Violento" in Matos, Raquel (ed.) Género, nacionalidade e reclusão. Olhares cruzados sobre migrações e reclusão feminina em Portugal. Universidade Católica do Porto.

${ }^{58}$ Individuals who maintain a family relationship with a citizen or holder who has acquired the nationality of a country of the EU (cf. Act 37/2006, August $9^{\text {th }}$ ).

59 'legal resident': a foreign national who holds a residence in Portugal, valid for a minimum of one year Act 23/07 of July 4, as amended by 29/12 of August 9, Article 3, paragraph v.

${ }^{60}$ Individuals originating from a third country who decide to spend some time (in tourism, study, internship, etc.) in another EU country without establishing their lives (cf. Guia, 2015).

${ }^{61}$ Although there is provision for access to rights, even if the victims do not want to cooperate in the investigation, as provided for in Decree-Law No. 368/2007 of 5 November. I considered, however, that because they are victims of crimes cannot be fully explained about the support that the State can grant them and so if they vote to maintain silence, it therefore enters into the lower level.
} 
space and are therefore obliged to return to their country of origin. This return is usually funded by the shipping companies ${ }^{62}$.

Figure 1 describes the image that emerged from an initial analysis of the stratification that emerged at a European level in Portuguese society ${ }^{63}$.

\section{Conclusions}

Reflecting upon the acceptance and integration of immigrants implies reflecting upon their rights and determining what is meant by citizenship in conjunction with nationality and irregularity. Depending on their legal/illegal status, it will take them more or less time to integrate into their host society. The relationship between the newly arrived migrant and the host state is nonlinear and dependent upon a number of variables unique to each state. It is this connection that usually determines access to rights in the host country for this new 'other'.

Since the ' 80 s, the concept of citizenship has been debated and discussed, particularly in the areas of migration. In countries that have traditionally been the recipients of immigration, the acquisition of nationality has been regarded as a step towards integration and access to citizenship ${ }^{64}$. Countries receiving only seasonal workers migrated are largely unaffected by this issue. ${ }^{65}$ However, several factors that contributed to this perception have changed: the will to access to political, social, and state rights, especially with applications for family reunification by non-nationals, spread the immigrant image to want to benefit from the State reserves, which helped to create a negative image ${ }^{66}$.

Although the number of countries have widened-especially in the European Union over the years-more and more rights have been enshrined in the statutes of foreign long-term residents, the granting of nationality without the loss of one's original

\footnotetext{
${ }^{62}$ Cfr. Article 41 of Act 23/2007 of July 4, as amended by Act 29/2012 of August 9.

${ }^{63}$ Further analysis will be considered in a longer reflection in a future article.

${ }^{64}$ In Portugal, according to João Pedroso (2011:372), held a '(...) break [among others, the right to family] comes from increased tolerance and inclusive policy towards foreigners and immigrants, to enable the acquisition of nationality Portuguese by marriage, that marriage and adoption'.

${ }^{65}$ BAUBÖCK, 2006

${ }^{66}$ Remember the case of migrants (Portuguese and Turkish) guests to rebuild Germany and, after a few years of work, requested the coming of the families, especially the wives, definitively, (some of which became pregnant two and more children), benefiting from the respective allowances for long periods of time. Now, at this time, to be regarded as 'freeloaders' of the facilities granted by the State. In this regard, see Bauman (2004: 66-67): 'Only three decades ago Portugal was (along with Turkey) the leading provider of 'guest workers' [the Gastarbeiter], the Germans Bürger feared looting and destroying their cities the social pact, pillar of your safety and comfort'.
} 
nationality, have allowed many immigrants to access citizenship in a situation nearequal to that of indigenous nationals. ${ }^{67}$ Transnational citizenship has been seen as a transformation of political belonging in the context of migration, most visibly manifested in the proliferation of multiple nationalities. ${ }^{68}$

Although the goal may be for citizens and foreign-nationals to have equality and respect, this is not the case in practice, and discrepancies and differential access remain in effect. This is mainly due to each individual's point of origin, how society was constructed and power spaces implemented (particularly given the economic and social ties that have been in place since the construction of the identity of the European Union), the bonds kept, family and intentions of each individual. We can therefore identify dissonance between individuals arriving from third countries, who can access regularisation, and those who come from European countries (EU or Schengen), where both groups lay down their lives, either by family ties or the protection granted by the host State, through what is stipulated by law. Also, the intention to remain for more or less time in the host countries, to develop a professional activity, among others, is taken into account for the determination of differential access ${ }^{69}$.

Irregular migration does not follow a simple logic, there are no single responses to irregular migration. Single, standalone measures cannot suffice. As such, this diversity must be considered. Regularisation is but one way to deal with some forms of irregularity, but not others. Moreover, regularisation may not be sufficient in some situations, in which case it should be considered on as a complementary measure.

The European Union is trying to find the best way to prevent irregularity, implementing policies that facilitate access to visas. The common visa policy and the databases that have been discussed for many years but have not yet been implemented, but aim to combat irregular immigration. ${ }^{70}$ Notwithstanding, if these measures are being taken with the express purposed of preventing crimes and facilitating access to

\footnotetext{
${ }^{67}$ There are certain rights that are only consigned to national origin citizens, as we analyse in a different article.

${ }^{68}$ BAUBÖCK, 2006

${ }^{69}$ This work did not have the ambition to reflect on asylum seekers on the grounds that, by itself, this was an autonomous subject.

${ }^{70}$ See the Communication from the Commission to the European Parliament, the Council, the European Economic and Social Committee and the Committee of the Regions of 17 June 2008 - A Common Immigration Policy for Europe: Principles, actions and tools [COM(2008) 359 final - Not published in the Official Journal]. [Accessed in 1.01.2010 Available at

http://europa.eu/legislation_summaries/justice_freedom_security/free_movement_of_persons_asylum_im $\underline{\text { migration/j10001_en.htm }}$
} 
European Union states, then efforts must be undertaken to preserve the rights of migrants who are permitted to stay.

As such, this paper demonstrates that the discussion around the terms used to identify this phenomenon are not linear. There are a multitude of positions and various meanings inherent to each one. We have also seen that policies used for managing irregular migration differ from one country to the next, and that each European Union state takes a different approach and has come up with different solutions. These 'solutions' sometimes result in inequalities, as we have seen, in terms of migration. In Portugal, there is a greater acceptance of migrants and efforts are taken to facilitate the integration of these migrants. Moreover, the state has taken measures to ensure that irregular migrants are given access to basic rights, like health, education, work and access to justice. Consequently, Portugal was recently regarded as the second best country in terms of migrant integration policies out of a group of 31 countries, and based on a set of 148 parameters. ${ }^{71}$

Nonetheless, this investigation is far from complete. Much is to be done in order to identify concrete challenges that lie ahead and the solutions the State has been providing when dealing with migrants in irregularity. There is always a better way when we think about human rights and respect for the other.

Artigo Recebido a 01 de março de 2016 I Aceite a 08 de junho de 2016

\footnotetext{
${ }^{71}$ MIPEX III "Migrant Integration Policy Index III: Portugal". Outcomes for Policy Change Program Report (European Fund for the Integration of Third-Country Nationals). 2011. British Council and Migration Policy Group.

http://www.acidi.gov.pt/_cfn/4d6b77b1c7065/live/Ver+relat\%C3\%B3rio+MIPEX+III [23 de janeiro de 2015].
} 